Article

\title{
Evaluation of Critical Limit of Sulphur in Soils for Wheat (Triticum aestivum L.) and Mustard (Brassica napus L.)
}

\author{
Rubina Yesmin ${ }^{1}$, Mahmud Hossain ${ }^{1}\left(\mathbb{D}\right.$, Mohammad Golam Kibria ${ }^{1}\left(\mathbb{D}\right.$, Mohammad Jahiruddin ${ }^{1}$, \\ Zakaria M. Solaiman ${ }^{2}$ D, Shaikh Mohammad Bokhtiar ${ }^{3}$, Md Baktear Hossain ${ }^{3}$, Md Abdus Satter ${ }^{3}$ \\ and Md Anwarul Abedin 1,*(D) \\ 1 Department of Soil Science, Bangladesh Agricultural University, Mymensingh 2202, Bangladesh; \\ ru_ag24@yahoo.com (R.Y.); mahmud.ss@bau.edu.bd (M.H.); kibria.ss@bau.edu.bd (M.G.K.); \\ m_jahiruddin@yahoo.com (M.J.) \\ 2 UWA School of Agriculture and Environment, The UWA Institute of Agriculture, M078, \\ Perth, WA 6009, Australia; zakaria.solaiman@uwa.edu.au \\ 3 Bangladesh Agricultural Research Council, Farmgate, Dhaka 1215, Bangladesh; \\ bokhtiarsm@yahoo.com (S.M.B.); baktear@gmail.com (M.B.H.); a.satter1959@gmail.com (M.A.S.) \\ * Correspondence: m.a.abedin@bau.edu.bd; Tel.: +880-1718031462
}

check for updates

Citation: Yesmin, R.; Hossain, M.; Kibria, M.G.; Jahiruddin, M.; Solaiman, Z.M.; Bokhtiar, S.M.; Hossain, M.B.; Satter, M.A.; Abedin, M.A. Evaluation of Critical Limit of Sulphur in Soils for Wheat (Triticum aestivum L.) and Mustard (Brassica napus L.). Sustainability 2021, 13, 8325 https://doi.org/10.3390/su13158325

Academic Editor: Primo Proietti

Received: 10 June 2021

Accepted: 19 July 2021

Published: 26 July 2021

Publisher's Note: MDPI stays neutral with regard to jurisdictional claims in published maps and institutional affiliations.

Copyright: (c) 2021 by the authors. Licensee MDPI, Basel, Switzerland. This article is an open access article distributed under the terms and conditions of the Creative Commons Attribution (CC BY) license (https:// creativecommons.org/licenses/by/ $4.0 /)$.

\begin{abstract}
The conception of critical limit (CL) of a nutrient element distinguishes its deficiency from sufficiency, which could advise fertilizer application. A pot culture experiment was conducted during Rabi season (2019-2020) to study the CL of sulphur (S) in soil and plant. A total of 20 soil samples collected from intensive cropping areas of three agroecological zones (AEZs) of Bangladesh were used in the experiment. The $0.15 \% \mathrm{CaCl}_{2}$ extractable $\mathrm{S}$ (expressed as available $\mathrm{S}$ ) contents of the test soils ranged from $6.84 \mathrm{mg} / \mathrm{kg}$ to $38 \mathrm{mg} / \mathrm{kg}$. Wheat (Triticum aestivum L.) cv. BARI gom 30 and mustard (Brassica napus L.) cv. BINA sorisha 9 were used as test crops in this study. There were two rates of $S$ application to soil- 0 and $15 \mathrm{mg} / \mathrm{kg}$ for wheat and 0 and $18 \mathrm{mg} / \mathrm{kg}$ for mustard from gypsum $\left(\mathrm{CaSO}_{4} \cdot 2 \mathrm{H}_{2} \mathrm{O}\right)$. Each $\mathrm{S}$ treatment was replicated thrice. Dry matter yield, $\mathrm{S}$ content and $\mathrm{S}$ uptake by the crops increased with added S. For mustard, the CL of soil $\mathrm{S}$ was estimated to be $14 \mathrm{mg} / \mathrm{kg}$ by graphical procedure and $11 \mathrm{mg} / \mathrm{kg}$ in statistical method while plant tissue concentration showed the CL of $0.35 \%$ in both methods. The CL of soil S for wheat was found to be $14 \mathrm{mg} / \mathrm{kg}$ and $11 \mathrm{mg} / \mathrm{kg}$ in graphical and statistical methods, respectively, and the CL of plant tissue concentration was recorded as $0.14 \%$, in both methods. It is expected that mustard and wheat crops would respond to $S$ fertilization in soils containing $S$ at or below the CL. The results would be useful for predicting crop (wheat and mustard) response to $S$ fertilizer and developing efficient $S$ fertilizer management to promote sustainable crop production.
\end{abstract}

Keywords: critical limit; MUSTARD; S content; S uptake; wheat

\section{Introduction}

Sulphur (S) is one of the essential plant nutrients, ranked as the fourth most important plant nutrient after nitrogen $(\mathrm{N})$, phosphorus $(\mathrm{P})$ and potassium $(\mathrm{K})$ [1]. It is a major component of S-containing amino acids and plays a vital role in forming chlorophyll, oils, etc., and enzyme activation. Optimum supply of $S$ can increase the nutritional value and yield, whereas S deficiency may cause an approximately 50\% decrease in crop yield [2]. The intensive agricultural system and cultivation of high yielding crops coupled with the limited supply of S fertilizers have accelerated S deficiency in arable lands [3], and S deficiency has become prominent in crop agriculture across the globe [4,5]. In Bangladesh, as in other parts of the world, crop production is limited by S deficiency in the soil [6]. At present, approximately 3.31 million hectares of land have been categorized as $S$ deficient soil in Bangladesh with an application rate of $8-12 \mathrm{~kg} / \mathrm{ha}$ [7]. Therefore, it is crucial 
to supply an adequate amount of $\mathrm{S}$ for maintaining better plant growth, development and yield.

Sulphur deficiency significantly affects the growth and development of crops, such as wheat [8-10] and mustard [11]. Wheat (Triticum aestivum) is one of the major three cereal crops in terms of global production, and the second most important cereal crop in Bangladesh after rice. Mustard (Brassica napus) is a major oilseed crop as well as a popular culinary herb of Bangladesh. Applying S fertilizers can increase wheat yield [12] and oil content of mustard [13]. For wheat, inadequate $S$ content limits nitrogen use efficiency [14], decreases grain size [8,9] and degrades baking quality [15]. In the case of mustard, $S$ is involved in increasing oil synthesis [16] and $\mathrm{S}$ is an important constituent of proteins, vitamins (biotin, thiamine) and S containing amino acids, i.e., cystine and methionine [17] It is essential to apply the $S$ containing fertilizers to address the $S$ deficiency in plants and avoid production loss when the $S$ content in soil goes below a certain level, i.e., critical limit. Therefore, it is crucial to identify an indicator that helps to know the time of fertilizer application to maintain crop growth and productivity.

Critical limit (CL) is an important indicator to determine the optimum fertilizer requirement for a crop. It is the level at or below which crops respond to the added particular nutrient. It separates a group of soils that give a significant yield response to fertilizers from that of soils that do not respond [18]. The CL or level is quite often employed for a wide variety of soils and crops, even though these CL may be different not only for soils, crop species but also for different varieties of the given crop [19,20]. Different critical values of available $S$ in a particular soil for mustard are reported for different extractants [21]. Moreover, these limits varied with the soil as well as the extractants used within the same soil [22]. It is important to identify a CL for S in soil to enable the farmers to maintain plant growth and productivity by applying $S$ containing fertilizers when the $S$ content in soils goes below the critical limit of specific soil and crops.

The main aim of this study was to determine the CL of $S$ in soils for efficient application of $\mathrm{S}$ fertilizer for wheat and mustard, predominantly grown in different agroecological zones of Bangladesh. There is not comparative report available regarding the approaches for determining the CL of S. Therefore, this study will also compare the graphical and statistical approaches used for determining the CL of $S$ in soils of Bangladesh for wheat and mustard cultivation.

\section{Materials and Methods}

\subsection{Soil Sampling, Analysis and Test Crops}

The soil samples $(0-15 \mathrm{~cm}$ soil depth) were collected from 20 different locations of three agroecological zones (AEZs) of Bangladesh; namely Old Himalayan Piedmont Plain (AEZ 1), Tista Meander Floodplain (AEZ 3) and Old Brahmaputra Floodplain (AEZ 9) comprising the districts Panchagarh, Rangpur and Mymensingh. The AEZs were developed mainly based on the soil characteristics and climatic condition, and Bangladesh has been divided into $30 \mathrm{AEZs}$, where the above mentioned AEZs have the highest cropping intensity. Due to the variation among the AEZs, the crop suitability is also different in different AEZs. The geographical positions and general features of the soil collection sites are presented in Table 1. The sampling location map has also been included in Figure 1. All soils were air-dried, sieved $(\leq 2 \mathrm{~mm})$ and mixed until homogenous. The collected soil samples were analysed to determine different physico-chemical properties of soil such as texture, $\mathrm{pH}$, organic matter and soil nutrients status following standard methods. The physico-chemical properties of the collected soil samples before starting the experiments are presented in Table 2. The non-draining plastic pots (4 kg capacity) were filled with $3 \mathrm{~kg}$ of soil. Wheat (Triticum aestivum) var. BARI gom 30 and mustard (Brassica napus L.) var. BINA sorisha 9 were used in this study as test crops. 
Table 1. Geographical position and general features of the soil samples collected from intensive cropping area of three agroecological zones.

\begin{tabular}{|c|c|c|c|c|c|c|}
\hline Sample ID & $\begin{array}{l}\text { Locations } \\
\text { (Upazillas) }\end{array}$ & AEZ No. & Soil Series & $\begin{array}{l}\text { Geographical } \\
\text { Location }\end{array}$ & Land Type & $\begin{array}{c}\text { Major Cropping } \\
\text { Pattern }\end{array}$ \\
\hline S1 & $\begin{array}{l}\text { Taraganj, } \\
\text { Rangpur }\end{array}$ & 3 & Kawnia & $25.48^{\circ} \mathrm{N} 89.05^{\circ} \mathrm{E}$ & MHL & Mustard-Boro-T. aman \\
\hline S2 & $\begin{array}{c}\text { Sadar, } \\
\text { Panchagarh }\end{array}$ & 1 & Vojonpur & $26.28^{\circ} \mathrm{N} 88.31^{\circ} \mathrm{E}$ & HL & Mustard-Boro-T. aman \\
\hline S3 & $\begin{array}{c}\text { Sadar, } \\
\text { Panchagarh }\end{array}$ & 1 & Vojonpur & $26.28^{\circ} \mathrm{N} 88.31^{\circ} \mathrm{E}$ & HL & Potato-T. aman-G. nut \\
\hline S4 & $\begin{array}{c}\text { Sadar, } \\
\text { Mymensingh }\end{array}$ & 9 & Sonatola & $24.39^{\circ} \mathrm{N} 90.27^{\circ} \mathrm{E}$ & MHL & Boro-Fellow-T. aman \\
\hline S5 & $\begin{array}{l}\text { Taraganj, } \\
\text { Rangpur }\end{array}$ & 3 & Polashbari & $25.48^{\circ} \mathrm{N} 89.04^{\circ} \mathrm{E}$ & MHL & Boro-Fellow-T. aman \\
\hline S6 & $\begin{array}{l}\text { Taraganj, } \\
\text { Rangpur }\end{array}$ & 3 & Sonatola & $25.48^{\circ} \mathrm{N} 89.05^{\circ} \mathrm{E}$ & MHL & Boro-Fellow-T. aman \\
\hline S7 & $\begin{array}{c}\text { Sadar, } \\
\text { Mymensingh }\end{array}$ & 9 & Sonatola & $24.39^{\circ} \mathrm{N} 90.27^{\circ} \mathrm{E}$ & HL & Mustard-Boro-T. aman \\
\hline S8 & $\begin{array}{c}\text { Sadar, } \\
\text { Panchagarh }\end{array}$ & 1 & Atoary & $26.27^{\circ} \mathrm{N} 88.33^{\circ} \mathrm{E}$ & MHL & Potato-Jute-T. aman \\
\hline S9 & Sadar, Rangpur & 3 & Gongachora & $25.48^{\circ} \mathrm{N} 89.07^{\circ} \mathrm{E}$ & MHL & Boro-Fellow-T. aman \\
\hline $\mathrm{S} 10$ & $\begin{array}{c}\text { Sadar, } \\
\text { Mymensingh }\end{array}$ & 9 & Sonatola & $24.40^{\circ} \mathrm{N} 90.27^{\circ} \mathrm{E}$ & MHL & Mustard-Boro-T. aman \\
\hline S11 & $\begin{array}{l}\text { Muktagacha, } \\
\text { Mymensingh }\end{array}$ & 9 & Sonatola & $24.47^{\circ} \mathrm{N} 90.12^{\circ} \mathrm{E}$ & HL & Mustard-Boro-T. aman \\
\hline S12 & $\begin{array}{c}\text { Sadar, } \\
\text { Mymensingh }\end{array}$ & 9 & Silmondi & $24.40^{\circ} \mathrm{N} 90.26^{\circ} \mathrm{E}$ & MHL & Boro-Fellow-T. aman \\
\hline $\mathrm{S} 13$ & $\begin{array}{c}\text { Tetulia, } \\
\text { Panchagarh }\end{array}$ & 1 & Pirgacha & $26.28^{\circ} \mathrm{N} 88.30^{\circ} \mathrm{E}$ & HL & Mustard-Jute-T. aman \\
\hline S14 & $\begin{array}{l}\text { Muktagacha, } \\
\text { Mymensingh }\end{array}$ & 9 & Silmondi & $24.44^{\circ} \mathrm{N} 90.12^{\circ} \mathrm{E}$ & MHL & Mustard-Boro-T. aman \\
\hline S15 & Sadar, Rangpur & 3 & Menanogor & $25.48^{\circ} \mathrm{N} 89.07^{\circ} \mathrm{E}$ & MHL & Tobacco-Aus-T. aman \\
\hline S16 & $\begin{array}{c}\text { Sadar, } \\
\text { Mymensingh }\end{array}$ & 9 & Silmondi & $24.40^{\circ} \mathrm{N} 90.26^{\circ} \mathrm{E}$ & MHL & Boro-Fellow-T. aman \\
\hline S17 & $\begin{array}{c}\text { Sadar, } \\
\text { Mymensingh }\end{array}$ & 9 & Sonatola & $24.40^{\circ} \mathrm{N} 90.27^{\circ} \mathrm{E}$ & MHL & Mustard-Boro-T. aman \\
\hline $\mathrm{S} 18$ & $\begin{array}{c}\text { Sadar, } \\
\text { Mymensingh }\end{array}$ & 9 & Silmondi & $24.40^{\circ} \mathrm{N} 90.26^{\circ} \mathrm{E}$ & MHL & Mustard-Boro-T. aman \\
\hline S19 & $\begin{array}{c}\text { Sadar, } \\
\text { Mymensingh }\end{array}$ & 9 & Silmondi & $24.40^{\circ} \mathrm{N} 90.26^{\circ} \mathrm{E}$ & MHL & Mustard-Boro-T. aman \\
\hline S20 & $\begin{array}{c}\text { Sadar, } \\
\text { Mymensingh }\end{array}$ & 9 & Silmondi & $24.40^{\circ} \mathrm{N} 90.26^{\circ} \mathrm{E}$ & MHL & Boro-Fellow-T. aman \\
\hline
\end{tabular}


Table 2. Soil physico-chemical properties of the collected soil samples before starting the experiments.

\begin{tabular}{|c|c|c|c|c|c|c|c|c|c|}
\hline $\begin{array}{c}\text { Sample } \\
\text { ID }\end{array}$ & $\begin{array}{l}\text { Textural- } \\
\text { Class }\end{array}$ & $\mathrm{pH} \mathrm{HaCl}_{\mathrm{Ca}}$ & $\begin{array}{c}\text { Total } \\
\text { OM (\%) }\end{array}$ & $\begin{array}{l}\text { Avail. P } \\
\text { (mg/kg) }\end{array}$ & $\begin{array}{c}\text { Total N } \\
(\%)\end{array}$ & $S(\mathrm{mg} / \mathrm{kg})$ & $\begin{array}{c}\mathrm{K} \\
\text { (cmolc/kg } \\
\text { Soil) }\end{array}$ & $\begin{array}{c}\text { Ca } \\
\text { (cmolc/kg } \\
\text { Soil) }\end{array}$ & $\begin{array}{c}\mathrm{Mg} \\
\text { (cmolc/kg } \\
\text { Soil) }\end{array}$ \\
\hline S1 & $\begin{array}{l}\text { Sandy } \\
\text { Loam }\end{array}$ & 5.10 & 2.46 & 14.88 & 0.12 & 6.84 & 0.13 & 1.16 & 0.27 \\
\hline S2 & $\begin{array}{l}\text { Sandy } \\
\text { Loam }\end{array}$ & 4.60 & 2.33 & 8.37 & 0.13 & 8.16 & 0.15 & 0.75 & 0.5 \\
\hline S3 & $\begin{array}{l}\text { Sandy } \\
\text { Loam }\end{array}$ & 4.96 & 2.00 & 16.74 & 0.10 & 8.82 & 0.13 & 0.65 & 0.54 \\
\hline S4 & Clay loam & 6.02 & 1.33 & 17.37 & 0.08 & 9.33 & 0.09 & 3.11 & 1.49 \\
\hline S5 & $\begin{array}{l}\text { Sandy } \\
\text { Loam }\end{array}$ & 4.61 & 1.86 & 35.54 & 0.10 & 9.87 & 0.14 & 1.1 & 0.17 \\
\hline S6 & $\begin{array}{l}\text { Sandy } \\
\text { Loam }\end{array}$ & 5.17 & 2.00 & 14.88 & 0.10 & 10.31 & 0.12 & 1.32 & 0.26 \\
\hline S7 & Loam & 5.87 & 2.06 & 12.74 & 0.08 & 10.82 & 0.13 & 5.73 & 1.35 \\
\hline S8 & $\begin{array}{l}\text { Sandy } \\
\text { Loam }\end{array}$ & 4.32 & 2.00 & 20.92 & 0.11 & 11.45 & 0.12 & 0.65 & 0.1 \\
\hline S9 & $\begin{array}{l}\text { Sandy } \\
\text { loam }\end{array}$ & 5.03 & 1.93 & 14.34 & 0.10 & 12.19 & 0.12 & 1.39 & 0.25 \\
\hline S10 & Clay loam & 5.78 & 1.66 & 12.74 & 0.08 & 13.06 & 0.10 & 4.77 & 2.04 \\
\hline $\mathrm{S} 11$ & Loam & 4.99 & 1.58 & 12.36 & 0.09 & 15.14 & 0.09 & 2.01 & 0.43 \\
\hline S12 & Clay & 6.03 & 1.80 & 15.83 & 0.08 & 15.30 & 0.14 & 6.51 & 3.07 \\
\hline S13 & Loam & 4.85 & 1.66 & 21.05 & 0.08 & 16.00 & 0.11 & 3.67 & 0.66 \\
\hline S14 & Loam & 5.43 & 1.46 & 10.04 & 0.07 & 22.08 & 0.11 & 4.12 & 1.31 \\
\hline S15 & Loam & 5.33 & 1.66 & 22.31 & 0.09 & 22.87 & 0.18 & 2.28 & 0.45 \\
\hline S16 & Clay loam & 6.11 & 1.80 & 9.27 & 0.09 & 24.25 & 0.16 & 8.18 & 3.75 \\
\hline S17 & Clay loam & 6.03 & 2.00 & 12.36 & 0.10 & 31.72 & 0.11 & 7.57 & 3.12 \\
\hline S18 & $\begin{array}{l}\text { Clay } \\
\text { Loam }\end{array}$ & 6.08 & 1.53 & 14.29 & 0.08 & 36.19 & 0.09 & 8.07 & 3.81 \\
\hline S19 & Clay & 5.90 & 1.60 & 12.36 & 0.07 & 36.94 & 0.11 & 8.17 & 4.01 \\
\hline S20 & Clay loam & 6.16 & 1.66 & 10.04 & 0.08 & 38.43 & 0.13 & 7.27 & 3.16 \\
\hline
\end{tabular}

OM, organic matter; P, phosphorus; $\mathrm{N}$, nitrogen; $\mathrm{S}$, sulphur; $\mathrm{K}$, potassium; Ca, calcium; $\mathrm{Mg}$, magnesium Note: Soil pH measured in water using a glass electrode and 1:2.5 soil-to- $\mathrm{CaCl}_{2}$ solution ratio [23]. Mechanical analysis of soils was done by hydrometer method [24] and the textural class was determined from Marshall's triangular co-ordinate following USDA system. Organic matter was determined by wet oxidation method [25], total N by micro-Kjeldahl method [26], available P for neutral and alkaline soil by Olsen method [27], available P for acidic soil by Bray and Kurtz method [28], and exchangeable bases ( $\mathrm{K}, \mathrm{Ca}$ and $\mathrm{Mg}$ ) were extracted with $1 \mathrm{M} \mathrm{NH}_{4} \mathrm{OAc}$ solution ( $\mathrm{pH}=7$ ) [29]. Available $\mathrm{S}$ was determined by extracting the soil sample with $0.15 \% \mathrm{CaCl}_{2}$ solution as described by Page et al. [30].

This experiment was conducted in early winter (November to December 2019) with an average day length of $11 \mathrm{~h}$ and an average day/night temperature of $22{ }^{\circ} \mathrm{C}$. Initially, 10 seeds were sown in each pot, and then after thinning six uniform plants were allowed to grow until harvesting. The pots were watered as per requirement, weeding and other intercultural operations were carried out as and when required. The plants were harvested 49 days after sowing (DAS) by cutting the shoots just above the soil surface. The plants were washed to removed dirt with running tap water followed by distilled water and were dried in an oven at $65^{\circ} \mathrm{C}$ for $48 \mathrm{~h}$, and the dry matter yield was recorded. The dried plant samples were ground and sieved through $2 \mathrm{~mm}$ sieve and kept for analysing plant nutrient content. Plant tissue concentration of $\mathrm{S}$ was determined following the turbidimetric method [31]. 


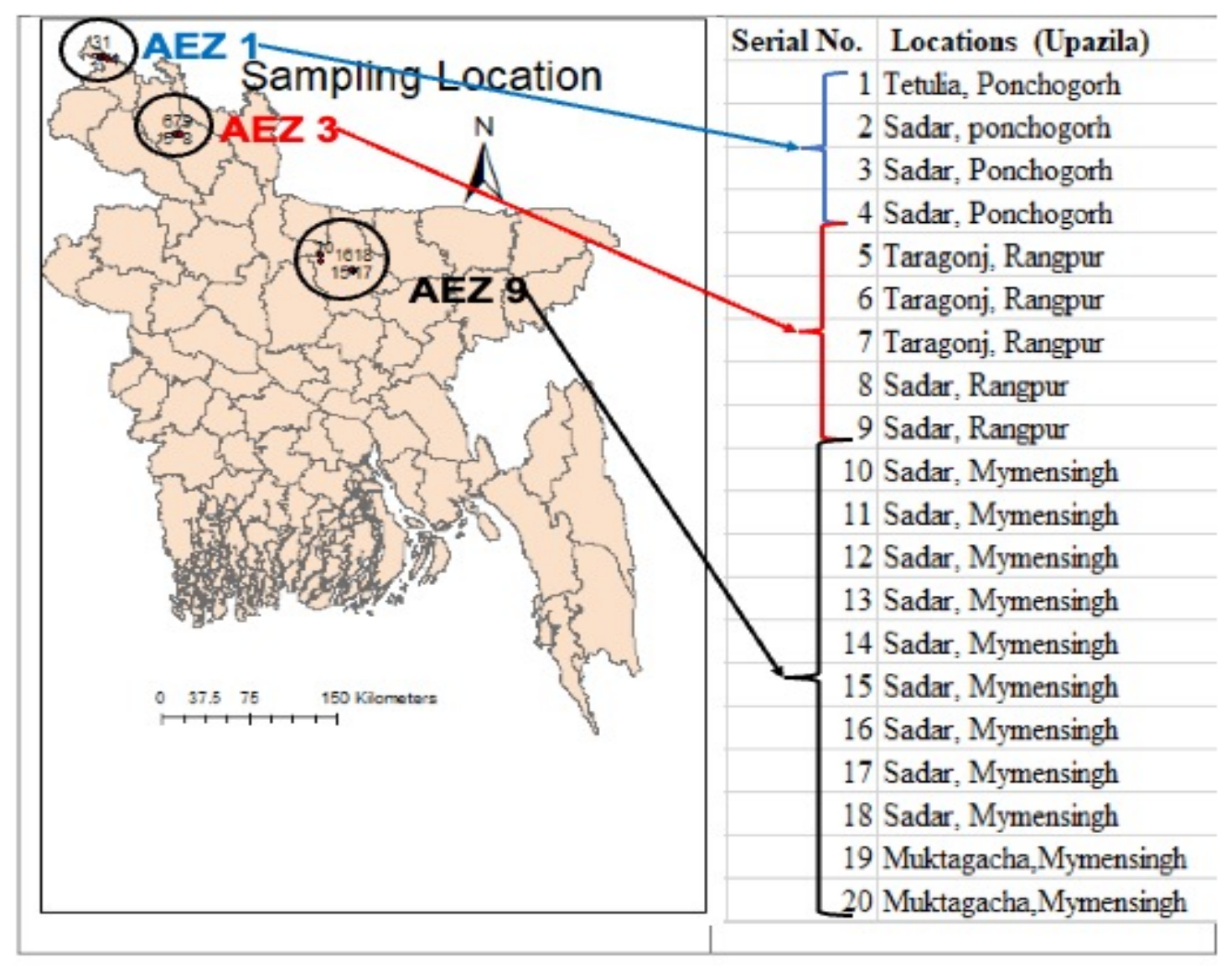

Figure 1. Soil sampling locations from three agroecological zones of Bangladesh.

\subsection{Experimental Design and Approach}

This study was conducted in the net house of the Soil Science Department of the Bangladesh Agricultural University (BAU) (Mymensingh, Bangladesh). The two-factorial experiment consisted of two levels of $S$ for each plant species $(0$ and $15 \mathrm{mg} / \mathrm{kg}$ soil or $32 \mathrm{~kg} / \mathrm{ha}$ for wheat and 0 and $18 \mathrm{mg} / \mathrm{kg}$ soil or $38 \mathrm{~kg} / \mathrm{ha}$ for mustard) and 20 soil samples collected from different AEZs with varying available $S$ (ranging from 6.84 to $38.43 \mathrm{mg} / \mathrm{kg}$ ), and was replicated three times using completely randomized design (six pots ( 2 sulphur rates $\times 3$ replication) for each soil and 120 pots ( 6 pots $\times 20$ soils) for each crop). All soils were amended with the following basal nutrients (in $\mathrm{mg} / \mathrm{kg}$ soil) mixed through the entire soil volume in each pot before sowing: $\mathrm{N}(70)$ from urea, $\mathrm{P}(20)$ from triple superphosphate and $\mathrm{K}(40)$ from muriate of potash. Reagent grade calcium sulphate $\left(\mathrm{CaSO}_{4} \cdot 2 \mathrm{H}_{2} \mathrm{O}\right)$ was used as the source of $\mathrm{S}$ for soil application.

\subsection{Critical Limit Determination by Graphical Method}

The CL of $\mathrm{S}$ was determined by the graphical method as described by Cate and Nelson [32]. A scatter diagram of the relative yields (Bray's percent dry matter yield) as Y-axis versus soil test values as X-axis was plotted. Bray's percent yield was calculated as follows:

$\%$ Relative yield $=($ Yield without nutrient addition/Yield with nutrient addition $) \times 100$

\subsection{Critical Limit Determination by Statistical Method}

In the statistical technique of determining critical level of $\mathrm{S}$, coefficient of determination $\left(R^{2}\right)$ was calculated as described by Waugh [33]. In this technique, the data are ordered in an array-based upon rankings of soil test values. The pairs of soil test value and relative 
yield were maintained in this order throughout the analyses. The procedure amounts to splitting the data into two groups, using successive tentative critical levels to determine the particular critical value. Accordingly, the predictability value $\left(R^{2}\right)$ was computed from the following relationship:

$$
\mathrm{R}^{2}=\left\{\mathrm{TCSS}-\left(\mathrm{CSS}^{1}+\mathrm{CSS}^{2}\right)\right\} / \mathrm{TCSS}
$$

where,

$$
\begin{aligned}
& \text { TCSS }=\text { Total Corrected Sum of Squares } \\
& \text { CSS }^{1}=\text { Corrected Sum of Squares of population } 1 \\
& \text { CSS }^{2}=\text { Corrected Sum of Squares of population } 2
\end{aligned}
$$

\subsection{Statistical Analysis}

The raw data observed from pot experiments were put for statistical analysis using two factorial Complete Randomized Design (CRD) to draw the valid differences among the treatments as well as soils. The data were subjected to two-way ANOVA and the significance of treatment on dry matter yield, concentration and uptake of $S$ by wheat and mustard plant was tested as described by Gomez and Gomez [34].

\section{Results}

The soils were analysed for physicochemical parameters presented in Table 2. Textural classes of the soils show that 7 soils were sandy loam, 6 soils were clay loam, 5 soils were loam and 2 soils were clay following the USDA system; which indicates a wide variation from relatively coarse to fine texture. Soil $\mathrm{pH}$ of the 20 test soils ranged from 4.32 (very strongly acidic: $<4.5$ ) to 6.16 (slightly acidic: $5.6-6.5$ ). The soil organic matter content of the soils varied from $1.33 \%$ (low) to $2.46 \%$ (high). Sulphur content in the soils varied from 6.84 to $38.43 \mathrm{mg} / \mathrm{kg}$; it was the basis for selecting the soils. The $\mathrm{S}$ content in a set of 12 soils varied from very low to low (6-15 mg/ $\mathrm{kg}), 4$ soils were medium $(16-24 \mathrm{mg} / \mathrm{kg})$ and 4 soils were high $(25-40 \mathrm{mg} / \mathrm{kg})$. Other major soil nutrient contents were also analysed to support the effect of $\mathrm{S}$ content in soil and its application on the growth of wheat and mustard. Nitrogen content between the soils varied from 0.07 to $0.13 \%$; P content from 8.37 to $35.54 \mathrm{mg} / \mathrm{kg}$ and $\mathrm{K}$ content from 0.09 to $0.14 \mathrm{cmol} / \mathrm{kg}$ soil. The range of $\mathrm{B}, \mathrm{Ca}$, $\mathrm{Mg}, \mathrm{Zn}, \mathrm{Cu}, \mathrm{Fe}$ and $\mathrm{Mn}$ of the 20 test soils were 0.15 to $0.94 \mathrm{mg} / \mathrm{kg}, 0.65$ to $8.18 \mathrm{mg} / \mathrm{kg}$, 0.54 to $3.75 \mathrm{mg} / \mathrm{kg}, 0.27$ to $2.04 \mathrm{mg} / \mathrm{kg}, 0.72$ to $3.82 \mathrm{mg} / \mathrm{kg}, 23$ to $120 \mathrm{mg} / \mathrm{kg}$ and 2.99 to $22.72 \mathrm{mg} / \mathrm{kg}$, respectively.

\subsection{Shoot Dry Matter Yield of Wheat and Mustard}

Sulphur application in soil ( $15 \mathrm{mg} / \mathrm{kg}$ soil) significantly increased shoot dry weight of wheat irrespective of initial $\mathrm{S}$ status in the soils ( $p \leq 0.05$; Table $3 \mathrm{a})$. The shoot dry weight varied from 2.67 to $3.63 \mathrm{~g} /$ pot (mean $3.12 \mathrm{~g} /$ pot) in the soil without $S$ amendment, whereas amending the soil with $\mathrm{S}(15 \mathrm{mg} / \mathrm{kg}$ soil) exhibited a significant increase in shoot dry weight varied from 3.05 to $4.11 \mathrm{~g} /$ pot (mean $3.54 \mathrm{~g} /$ pot). In control plants $(0 \mathrm{~kg} \mathrm{~S} / \mathrm{ha}$ ), the lowest dry matter yield was recorded in soil with very low concentration of inherent soil $\mathrm{S}$ (6.84 mg/kg; S1: Taraganj), and the highest dry matter yield was obtained in soils having inherent soil S of $11.45 \mathrm{mg} / \mathrm{kg}$ (S8: Panchagarh). Notably, the highest shoot dry matter yield of wheat was also observed in the soils of Panchagarh Sadar Upazila (AEZ 1) by applying $S$ to soil (15 mg S/ $\mathrm{kg}$ soil), and the lowest was also in the soils of Taraganj (AEZ 3). The Bray's percent $S$ yield of wheat ranged from 78 to $93 \%$ (mean $88.5 \%$ ) depending on the soils. 
Table 3. Effect of sulphur (S) application on dry matter yield, S concentration and its uptake by wheat and mustard plants.

\begin{tabular}{|c|c|c|c|c|c|c|c|c|}
\hline \multicolumn{9}{|c|}{ (a). Wheat } \\
\hline \multirow[t]{2}{*}{ Sample ID } & \multirow{2}{*}{$\begin{array}{c}\text { Soil } \\
\text { Available } \\
\text { S (mg/kg) }\end{array}$} & \multicolumn{2}{|c|}{$\begin{array}{l}\text { Dry Matter (g/pot) } \\
\text { S Level (mg/kg) }\end{array}$} & \multirow{2}{*}{$\begin{array}{l}\text { Bray's \% S } \\
\text { Yield }\end{array}$} & \multicolumn{2}{|c|}{$\begin{array}{l}\text { S Concentration in Plants } \\
(\%) S \text { Level }(\mathrm{mg} / \mathrm{kg})\end{array}$} & \multicolumn{2}{|c|}{$\begin{array}{l}\text { S Uptake (mg/pot) } \\
\text { S Level (mg/kg) }\end{array}$} \\
\hline & & 0 & 15 & & 0 & 15 & 0 & 15 \\
\hline $\mathrm{S} 1$ & 6.84 & 2.67 & 3.43 & 78 & 0.11 & 0.14 & 3.05 & 4.83 \\
\hline $\mathrm{S} 2$ & 8.16 & 3.30 & 4.00 & 83 & 0.12 & 0.15 & 4.03 & 5.80 \\
\hline S3 & 8.82 & 2.90 & 3.43 & 85 & 0.12 & 0.14 & 3.57 & 4.82 \\
\hline $\mathrm{S} 4$ & 9.33 & 3.50 & 4.04 & 87 & 0.14 & 0.16 & 4.90 & 6.58 \\
\hline S5 & 9.87 & 3.40 & 3.98 & 86 & 0.13 & 0.15 & 4.65 & 6.06 \\
\hline S6 & 10.31 & 2.94 & 3.49 & 84 & 0.13 & 0.15 & 3.92 & 5.31 \\
\hline S7 & 10.82 & 3.17 & 3.57 & 89 & 0.14 & 0.16 & 4.55 & 5.68 \\
\hline S8 & 11.45 & 3.63 & 4.11 & 88 & 0.14 & 0.16 & 5.07 & 6.56 \\
\hline S9 & 12.19 & 2.63 & 3.05 & 86 & 0.17 & 0.20 & 4.53 & 5.98 \\
\hline $\mathrm{S} 10$ & 13.06 & 2.83 & 3.13 & 90 & 0.16 & 0.18 & 4.50 & 5.52 \\
\hline S11 & 15.14 & 3.16 & 3.51 & 90 & 0.15 & 0.17 & 4.84 & 6.02 \\
\hline $\mathrm{S} 12$ & 15.30 & 3.11 & 3.54 & 92 & 0.17 & 0.19 & 5.37 & 6.87 \\
\hline $\mathrm{S} 13$ & 16.00 & 2.70 & 3.10 & 90 & 0.15 & 0.17 & 4.07 & 5.38 \\
\hline S14 & 22.08 & 2.86 & 3.13 & 91 & 0.15 & 0.16 & 4.40 & 5.12 \\
\hline S15 & 22.87 & 3.23 & 3.47 & 93 & 0.16 & 0.17 & 5.16 & 5.92 \\
\hline $\mathrm{S} 16$ & 24.25 & 3.15 & 3.45 & 91 & 0.18 & 0.20 & 5.79 & 6.79 \\
\hline S17 & 31.72 & 3.40 & 3.76 & 91 & 0.15 & 0.17 & 5.03 & 6.23 \\
\hline $\mathrm{S} 18$ & 36.19 & 3.38 & 3.68 & 92 & 0.16 & 0.17 & 5.39 & 6.36 \\
\hline S19 & 36.94 & 3.21 & 3.48 & 92 & 0.17 & 0.19 & 5.21 & 6.42 \\
\hline S20 & 38.43 & 3.14 & 3.37 & 93 & 0.17 & 0.18 & 5.37 & 6.22 \\
\hline Mean & 17.98 & 3.11 & 3.54 & 88.5 & 0.15 & 0.17 & 4.67 & 5.92 \\
\hline $\mathrm{P}$ at $5 \%$ & \multicolumn{3}{|c|}{ LSD [S (0.45); Soil (0.38)] } & \multicolumn{3}{|c|}{ LSD [S (0.002); Soil (0.002)] } & \multicolumn{2}{|c|}{ LSD [S (0.27); Soil (0.22) } \\
\hline \multicolumn{9}{|c|}{ (b). Mustard } \\
\hline \multirow[t]{2}{*}{ Sample ID } & \multirow{2}{*}{$\begin{array}{c}\text { Soil } \\
\text { Available } \\
\text { S (mg/kg) }\end{array}$} & \multicolumn{2}{|c|}{$\begin{array}{l}\text { Dry Matter (g/pot) } \\
\text { S Level (mg/kg) }\end{array}$} & \multirow{2}{*}{$\begin{array}{c}\text { Bray's \% S } \\
\text { Yield }\end{array}$} & \multicolumn{2}{|c|}{$\begin{array}{l}\text { S Concentration in Plants } \\
(\%) \text { S Level (mg/kg) }\end{array}$} & \multicolumn{2}{|c|}{$\begin{array}{l}\text { S Uptake (mg/pot) } \\
\text { S Level (mg/kg) }\end{array}$} \\
\hline & & 0 & 18 & & 0 & 18 & 0 & 18 \\
\hline S1 & 6.84 & 2.82 & 3.60 & 76 & 0.26 & 0.34 & 7.3 & 12.3 \\
\hline $\mathrm{S} 2$ & 8.16 & 3.03 & 3.97 & 80 & 0.28 & 0.35 & 8.4 & 14.1 \\
\hline S3 & 8.82 & 3.23 & 4.08 & 79 & 0.29 & 0.37 & 8.9 & 15.0 \\
\hline $\mathrm{S} 4$ & 9.33 & 3.17 & 3.91 & 81 & 0.30 & 0.37 & 9.7 & 14.4 \\
\hline S5 & 9.87 & 3.95 & 4.73 & 83 & 0.34 & 0.41 & 11.7 & 19.6 \\
\hline S6 & 10.31 & 3.21 & 3.82 & 84 & 0.34 & 0.41 & 11 & 15.5 \\
\hline S7 & 10.82 & 2.94 & 3.41 & 86 & 0.35 & 0.41 & 10 & 14.2 \\
\hline S8 & 11.45 & 3.06 & 3.62 & 85 & 0.35 & 0.41 & 10.9 & 15.0 \\
\hline S9 & 12.19 & 3.29 & 3.76 & 85 & 0.34 & 0.4 & 11.5 & 14.9 \\
\hline $\mathrm{S} 10$ & 13.06 & 3.80 & 4.39 & 87 & 0.35 & 0.4 & 13.5 & 18.2 \\
\hline S11 & 15.14 & 3.37 & 3.83 & 88 & 0.38 & 0.43 & 12.9 & 16.4 \\
\hline S12 & 15.30 & 3.24 & 3.63 & 89 & 0.38 & 0.42 & 12.1 & 15.2 \\
\hline
\end{tabular}


Table 3. Cont.

\begin{tabular}{|c|c|c|c|c|c|c|c|c|}
\hline \multicolumn{9}{|c|}{ (b). Mustard } \\
\hline \multirow[t]{2}{*}{ Sample ID } & \multirow{2}{*}{$\begin{array}{c}\text { Soil } \\
\text { Available } \\
\text { S (mg/kg) }\end{array}$} & \multicolumn{2}{|c|}{$\begin{array}{l}\text { Dry Matter (g/pot) } \\
\text { S Level (mg/kg) }\end{array}$} & \multirow{2}{*}{$\begin{array}{l}\text { Bray's \% S } \\
\text { Yield }\end{array}$} & \multicolumn{2}{|c|}{$\begin{array}{l}\text { S Concentration in Plants } \\
(\%) S \text { Level (mg/kg) }\end{array}$} & \multicolumn{2}{|c|}{$\begin{array}{l}\text { S Uptake (mg/pot) } \\
\text { S Level (mg/kg) }\end{array}$} \\
\hline & & 0 & 18 & & 0 & 18 & 0 & 18 \\
\hline S13 & 16.00 & 2.91 & 3.24 & 90 & 0.37 & 0.41 & 10.8 & 13.1 \\
\hline S14 & 22.08 & 3.47 & 3.82 & 91 & 0.41 & 0.45 & 13.4 & 17.2 \\
\hline S15 & 22.87 & 3.06 & 3.34 & 92 & 0.39 & 0.42 & 11.9 & 14.2 \\
\hline S16 & 24.25 & 3.23 & 3.50 & 92 & 0.41 & 0.44 & 13.1 & 15.3 \\
\hline S17 & 31.72 & 3.31 & 3.61 & 92 & 0.40 & 0.43 & 13.1 & 15.6 \\
\hline $\mathrm{S} 18$ & 36.19 & 3.77 & 4.04 & 93 & 0.39 & 0.42 & 14.6 & 16.9 \\
\hline S19 & 36.94 & 3.28 & 3.57 & 92 & 0.38 & 0.41 & 12.4 & 14.8 \\
\hline $\mathrm{S} 20$ & 38.43 & 3.33 & 3.59 & 93 & 0.37 & 0.40 & 12.3 & 14.3 \\
\hline Mean & 17.98 & 3.27 & 3.77 & 86.9 & 0.35 & 0.41 & 11.5 & 15.3 \\
\hline $\mathrm{P}$ at $5 \%$ & \multicolumn{3}{|c|}{ LSD [S (0.24); Soil (0.23)] } & \multicolumn{3}{|c|}{ LSD [S (0.03); Soil (0.03)] } & \multicolumn{2}{|c|}{ LSD [S (2.8); Soil (1.4)] } \\
\hline
\end{tabular}

The shoot dry matter yield of mustard was significantly increased by $\mathrm{S}$ application to soils ( $p \leq 0.05$; Table $3 \mathrm{~b}$ ). The shoot dry weight varied from 2.82 to $3.95 \mathrm{~g} / \mathrm{pot}$ (mean $3.27 \mathrm{~g} / \mathrm{pot})$ in the soil without $\mathrm{S}$ amendment, whereas amending the soil with $\mathrm{S}(18 \mathrm{mg} / \mathrm{kg}$ soil) exhibited a significant increase in shoot dry weight varied from 3.60 to $4.73 \mathrm{~g} / \mathrm{pot}$ (mean $3.77 \mathrm{~g} /$ pot). In control, the lowest shoot dry matter yield was observed in the soil with a deficient concentration of inherent soil S $(6.84 \mathrm{mg} / \mathrm{kg})$, and the highest dry matter yield was obtained in the soils having inherent soil S of $9.87 \mathrm{mg} / \mathrm{kg}$. In S amended soil (18 mg S/ $\mathrm{kg}$ soil), the highest dry matter yield $(4.73 \mathrm{~g} / \mathrm{pot})$ was recorded in the soils of Taraganj Upazila and the lowest ( $3.24 \mathrm{~g} /$ pot) was observed in the soils of Tetulia Upazila of AEZ 1, irrespective of the nature of soils. The Bray's percent $S$ yield of mustard ranged from 76 to $93 \%$ (mean $86.9 \%$ ) depending on the soils.

\subsection{Sulphur Concentration and Uptake by Plants}

Applying $S$ to soil ( $15 \mathrm{mg} / \mathrm{kg}$ soil) significantly increased plant $\mathrm{S}$ concentration and uptake of wheat plants growing in different soils $(p \leq 0.05$; Table 3a). In control plants ( $0 \mathrm{~kg} \mathrm{~S} / \mathrm{ha}$ ), $\mathrm{S}$ concentration in wheat plants ranged from 0.11 to $0.18 \%$ (mean $0.15 \%$ ), and in $\mathrm{S}$ amended soils ( $15 \mathrm{mg} \mathrm{S} / \mathrm{kg}$ soil) the concentration varied from 0.14 to $0.20 \%$ (mean $0.16 \%$ ). In control plants, S uptake by wheat varied from 3.05 to $5.79 \mathrm{mg} /$ plant (mean $4.67 \mathrm{mg} /$ plant) and 4.82 to $6.87 \mathrm{mg} /$ plant with an average of $5.92 \mathrm{mg} /$ plant in S amended soil treatments.

In mustard, application of $S$ (at $18 \mathrm{mg} / \mathrm{kg}$ soil) significantly increased plant $S$ concentration and uptake of plants growing in different soils ( $p \leq 0.05$; Table $3 b)$. In control plants ( $0 \mathrm{~kg} \mathrm{~S} / \mathrm{ha}$ ), S concentration in wheat plants ranged from 0.26 to $0.41 \%$ (mean $0.35 \%$ ), and in S amended soils (18 $\mathrm{mg} \mathrm{S} / \mathrm{kg}$ soil) the concentration varied from 0.34 to $0.45 \%$ (mean $0.41 \%$ ). In control plants, S uptake by wheat varied from 7.3 to $14.6 \mathrm{mg} / \mathrm{plant}$ (mean $11.5 \mathrm{mg} /$ plant) and 12.3 to $19.6 \mathrm{mg} /$ plant with an average of $15.3 \mathrm{mg} / \mathrm{plant}$ in S amended soil treatments.

\subsection{Critical Limit of $S$ for Wheat and Mustard}

The CL of $S$ concentration for wheat (49 DAS) was $0.14 \%$ (Figure 2a) using the graphical approach. In statistical procedure, the results also showed the same CL of $S$ concentration $(0.14 \%$, see Table S1), below which a plant will be regarded as S deficient at the specified growth period. Hence, it would require an external S application. Similar to wheat, the critical S concentration of mustard plants ( $49 \mathrm{DAS}$ ) was found to be $0.35 \%$ both in graphical 
(Figure 2b) and statistical approaches (Table S2), below which a plant will be regarded as $\mathrm{S}$ deficient at the specified growth period, and hence it would require an external S application.
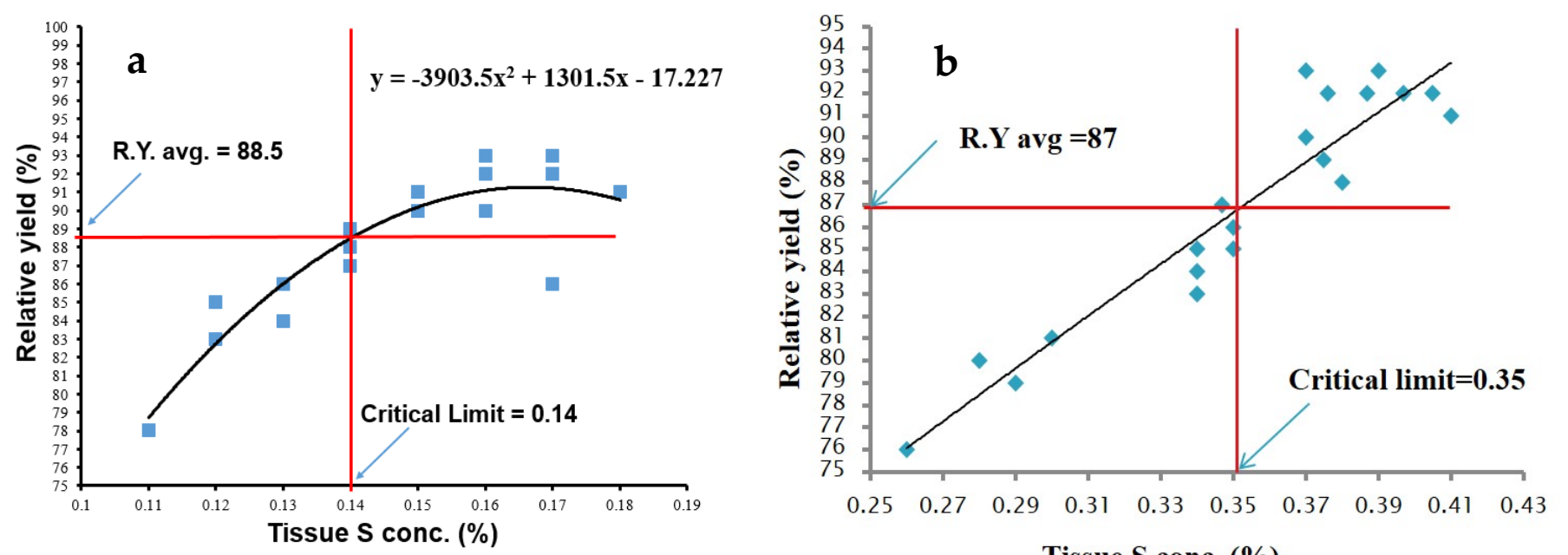

Tissue $\mathrm{S}$ conc. (\%)

Figure 2. Scatter diagram showing relationship between Bray's per cent yield and tissue sulphur (S) concentration in (a) wheat and (b) mustard plants for determining critical limit of $S$ for wheat and mustard cultivation.

\subsection{Critical Limit of Soil S Concentration for Wheat and Mustard}

The CL of available $S$ in the present study was found to be $13.5 \mathrm{mg} / \mathrm{kg}$ (Figure 3a). It is expected that wheat plants will respond to $S$ application when the soils contain less than $13.5 \mathrm{mg} / \mathrm{kg}\left(\mathrm{CaCl}_{2}\right.$ extractable $\left.\mathrm{S}\right)$. In statistical method, the $\mathrm{CL}$ of $\mathrm{S}$ in soil for wheat was $11.45 \mathrm{mg} / \mathrm{kg}$ (Table S3). From the critical level of $S$ in soils, it is evident that $S$ application rate below $15 \mathrm{mg} / \mathrm{kg}$ of soil cannot be helpful for the crop to alleviate the deficiency stress.

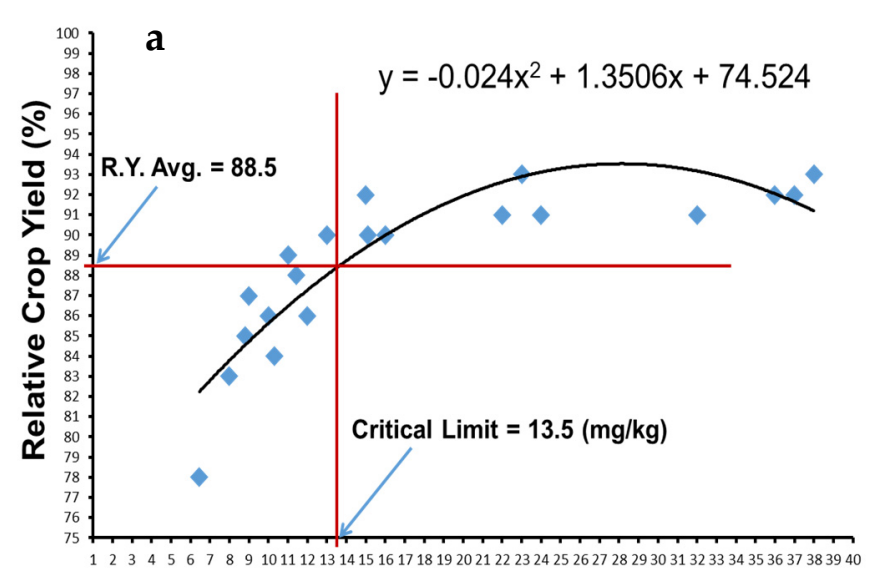

Soil Available S (mg/kg)

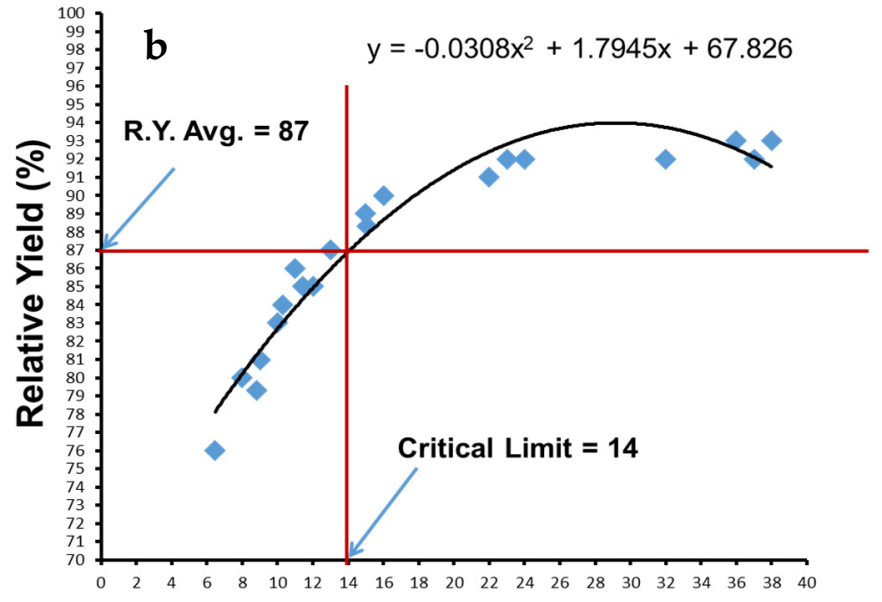

Soil Available S (mg/kg)

Figure 3. Scatter diagram showing the relationship between Bray's per cent yield of (a) wheat and (b) mustard for determining critical limit of sulphur for wheat and mustard cultivation.

The CL of available $S$ in the present study was $14 \mathrm{mg} / \mathrm{kg}$ (Figure $3 \mathrm{~b}$ ). The CL of $\mathrm{S}$ increased because of the intensive cropping system and limited application of organic matter in soil; thus, the soil remains deficient in S content in soil. It is expected that mustard plants will respond to $S$ application when the soils contain less than $14 \mathrm{mg} / \mathrm{kg}\left(\mathrm{CaCl}_{2}\right.$ extractable S). In statistical method the CL of S for mustard soil was $11.45 \mathrm{mg} / \mathrm{kg}$ (Table S4). From the critical level of $S$ in soils, it can be précised that $S$ application rate below $18 \mathrm{mg} / \mathrm{kg}$ of soil cannot be helpful for the crop to alleviate the deficiency stress. 


\section{Discussion}

The present study has determined the $\mathrm{S}$ level in soil below which wheat and mustard might respond to the added $\mathrm{S}$ containing fertilizers. For example, the results from this study demonstrated that the CL of $\mathrm{S}$ for wheat and mustard was 13.5 and $14 \mathrm{mg} / \mathrm{kg}$ soil, respectively. At present, all versions of the fertilizer recommendation guide employed in Bangladesh for fertilizer rate use $10 \mathrm{mg} \mathrm{S} / \mathrm{kg}$ soil as critical level [35]. The mentioned CL of $S$ in this present study is higher than the current value for fertiliser recommendation. This increase in CL of $S$ can be explained by the intensive cropping system and limited application of organic matter in soil (i.e., compost, farmyard manure etc.). Considering the critical level of $S$ in soils, it is evident that $S$ application rate below $14 \mathrm{mg} / \mathrm{kg}$ of soil cannot alleviate the $S$ deficiency of plants. The CL of $S$ in plant tissue can also be used as an indicator to determine the time and requirement of $S$ application instead of soil test values. Based on the present study, the tissue $S$ concentration was $0.14 \%$ for wheat and $0.35 \%$ for mustard. It is already established that after $\mathrm{S}$ application, $\mathrm{S}$ becomes available to make it more effective when applied at optimum dose and right time [36]. The CL of a nutrient in soil varies according to crops, soil and extraction methods. Concerning soil factors, what is important here is the soil type (S deficiency occur most often in sandy soil), soil $\mathrm{pH}$ (available at low soil $\mathrm{pH}$ ) and soil organic matter, as they influence the $\mathrm{S}$ availability in soil. Limited organic matter content in soil also triggers the deficiency of $S$ in soil, as it serves as a source of $S$ in soil. Hence, this situation justifies the need to determine and update the $\mathrm{CL}$ of different plant nutrients to formulate an optimum dose of deficient nutrients for different crops and soils. The basic objective is to achieve a satisfactory crop yield. However, the $\mathrm{CL}$ will remain changing due to the current farming practices and frequent monitoring is essential to maximize the fertilizer use efficiency and maintain a sustainable production system.

The CL of S may vary among the graphical and statistical approaches for determining the critical level. The results from this present study highlighted that the CL for wheat and mustard was 13.5 and $14 \mathrm{mg} / \mathrm{kg}$ soil, in graphical method. In contrast, the CL of S was lower $(11.45 \mathrm{mg} / \mathrm{kg}$ soil) for both crops in statistical method. The lower value in the statistical approach might occur due to available soil $\mathrm{S}$ corresponding to a corrected sum of squares for the population in this study to calculate predictability value $\left(R^{2}\right)$. However, this dispute requires further investigation to know why the $C L$ is lower in statistical method than the graphical method. It has already been reported that the statistical approach for determining CL provides a lower value than the graphical approach [35]. As the CL value is closer to each other, researchers can use any methods of determining the CL of nutrients in soil. We recommend using the highest critical value derived from the graphical and statistical approach to ensure higher crop yield as the larger percentage of soils will fail to comply with the CL. However, further research work is required to validate the findings from this present study. A good method should be able to predict the amount of plantavailable nutrient and the fertilizer responsiveness of crops growing on a wide range of soils. In this regard, the determination of CL using two different approaches is essential to determine an average crop's optimum fertilizer requirement [35].

A set of 20 representative soil was selected from 720 soils collected from throughout Bangladesh covering a wide range in texture, AEZ, general soil type, cropping pattern and land type. Among the 20 soils, six soils were collected from each of Sonatala and Silmondi soil series. Another eight soils included two from Vojonpur and one sample from Kawnia, Polashbari, Atoary, Gonggachora, Pirgacha, and Menanagar soil series. Of the representative soils, 14 were medium high land (MHL), and the remaining six were high land (HL) in their land types. The soils were dominated by rice-based cropping patterns and belong to subtropical monsoon climates with a wide variation in rainfall pattern, temperature and humidity. T. Aman rice was common in all the cropping patterns. Mustard was grown in 10 cropping patterns while wheat was not present in any of the patterns, though AEZ 1 and AEZ 3 are popular as wheat-growing areas in Bangladesh [7]. As the soil samples were collected from diversified regions of Bangladesh, the soil analysis 
showed variation in S content and other physico-chemical properties of soil. The diversified sampling approach might be the underlying reason for varying critical value of $\mathrm{S}$ for wheat and maize [7]. This dispute has also been supported by Murthy [21], who also described that variation among the sampling sites produces significant variation in CL of nutrients.

Applying $S$ to soil significantly increased the shoot dry biomass of crops grown in different soils. For example, application of $S$ to soil exhibited an approximately $12 \%$ increase in shoot dry biomass (averaged across wheat and mustard) compared to when no $S$ was applied to soil. The accumulation of dry matter is a vital crop growth index commonly used to determine the economic returns influenced by the effects of different treatments. Sulphur is often considered a limiting factor for shoot biomass yield in crop ecosystems [37]. The results agree with Huda et al. [38], who reported that application of $S$ containing fertilizers based on the critical limit of $S$ increases shoot biomass of rice. The improvements in shoot biomass yield obtained in this study might have resulted from the efficient uptake and metabolism of available S [39]. Thus, the application of $S$ to soil at or above the CL will help to increase crop growth and productivity across the different soil types.

\section{Conclusions}

We conclude that application of S significantly increased shoot dry matter yield and S uptake of wheat over mustard irrespective of soils. Using the graphical method, the CL of available $S$ for soil in wheat was found to be $13.5 \mathrm{mg} / \mathrm{kg}$ and for mustard $14 \mathrm{mg} / \mathrm{kg}$. In the statistical method it was found $11.45 \mathrm{mg} / \mathrm{kg}$ for soil of both wheat and mustard, which was higher than the present CL (10 mg/ $\mathrm{kg}$ soil). Critical plant tissue concentration of $S$ was $0.14 \%$ for wheat and $0.35 \%$ for mustard at the specified growth period (i.e., 7 weeks) both in graphical and statistical approaches. The findings from this study can be used for updating fertilizer recommendation guides for efficient fertilizer application in Bangladesh. This study may also ensure that $\mathrm{S}$ fertilization would be crucial for getting a higher economic yield of mustard and sustainable soil S management below the specified level. However, future research should focus on validating the results from the present study in the actual field condition.

Supplementary Materials: The following are available online at https:/ /www.mdpi.com/article/ $10.3390 /$ su13158325/s1, Table S1. Soil available S, Bray's \% yield and predictability values $\left(R^{2}\right)$ of wheat plant, Table S2. Soil available S, Bray's \% yield and predictability values $\left(R^{2}\right)$ of mustard plant, Table S3. Soil available S, Bray's per cent yield and predictability values $\left(R^{2}\right)$ of soil used for wheat cultivation, Table S4. Soil available S, Bray's percent yield and predictability values $\left(R^{2}\right)$ of soil used for mustard cultivation.

Author Contributions: Conceptualization and experimental design, M.A.A., M.J., S.M.B., M.B.H., M.A.S. and M.H.; research and data collection, R.Y.; data analysis, M.A.A. and M.H.; writingoriginal draft, R.Y.; writing—reviewing and editing, M.G.K., M.H., M.J. and Z.M.S.; supervision, M.A.A.; funding, S.M.B. and M.B.H. All authors have read and agreed to the published version of the manuscript.

Funding: This research project was funded by PBRG (134)-NATP2 by the World Bank, IFAD and the Government of Bangladesh.

Institutional Review Board Statement: Not applicable. The study did not involve any humans or animals.

Informed Consent Statement: Not applicable. This study did not involve humans.

Data Availability Statement: The data is available from the corresponding author upon reasonable request.

Acknowledgments: The authors acknowledge the financial support from the World Bank, IFAD and the Government of Bangladesh, and the logistic support from the staff of the Department of Soil Science, Bangladesh Agricultural University in collecting soil and conducting experiments. 
Conflicts of Interest: No conflict of interest.

\section{References}

1. Messick, D.L.; Fan, M.X.; Brey, C.D. Global sulfur requirement and sulfur fertilizers. Landbauforsch Völkenrode 2005, 283, 97-104.

2. Zhao, F.J.; McGrath, S.P.; Hawkesford, M.J. Sulphur Nutrition and the Sulphur Cycle. Institute of Arable Crops, (Research Report 2000-2001); Rothamsted Experimental Station: Harpenden, UK, 2001; p. 21.

3. Bender, R.R.; Haegele, J.W.; Ruffo, M.L.; Below, F.E. Nutrient uptake, partitioning, and remobilization in modern, transgenic insect-protected maize hybrids. Agron. J. 2013, 105, 161-170. [CrossRef]

4. Scherer, H.W. Sulphur in crop production-Invited paper. Eur. J. Agron. 2001, 14, 81-111. [CrossRef]

5. Haneklaus, S.; Bloem, E.; Schnug, E. History of sulfur deficiency in crops. In Sulfur: A Missing Link between Soils, Crops, and Nutrition; Jez, J., Ed.; ASA-CSSA-SSSA: Masidon, WI, USA, 2008; pp. 45-58.

6. Chowdhury, M.A.H. Dynamics of Microbial Biomass Sulphur in Soil and Its Role in Sulphur Availability to Plants. Ph.D. Thesis, Hiroshima University, Hiroshima, Japan, 2000.

7. SRDI. Land and Soil Statistical Appraisal Book of Bangladesh; Soil Resource Development Institute: Dhaka, Bangladesh, 2000.

8. Zhao, F.J.; Hawkesford, M.J.; McGrath, S.P. Sulphur Assimilation and Effects on Yield and Quality of Wheat. J. Cereal. Sci. 1999, 30, 1-17. [CrossRef]

9. McGrath, S.P. Sulphur: A secondary nutrient? Not anymore! New AG International. March 2003, pp. 70-76. Available online: https:/ / repository.rothamsted.ac.uk/item/89029/sulphur-a-secondary-not-anymore (accessed on 21 July 2021).

10. Gyori, Z. Sulphur content of winter wheat grain in long term field experiments. Commun. Soil Sci. Plant. Anal. 2005, 36, 373-382. [CrossRef]

11. Khan, N.; Jan, A.; Ihsanullah, I.; Khan, A.; Khan, N. Response of canola to nitrogen and sulphur nutrition. Asian J. Plant Sci. 2002, 1, 516-518. [CrossRef]

12. Xie, Y.X.; Zhang, H.; Zhu, Y.J.; Zhao, L.; Yang, J.H.; Cha, F.N.; Liu, C.; Wang, C.Y.; Guo, T.C. Grain yield and water use of winter wheat as affected by water and sulfur supply in the North China Plain. J. Integr. Agric. 2017, 16, 614-625. [CrossRef]

13. Panda, P.K.; Sounda, S.; Tripathy, S.K. Effect of irrigation and sulphur on yield, nutrient uptake and quality of mustard. J. Oilseeds Res. 2000, 17, 122-126.

14. Sahota, T.S. Importance of Sulphur in Crop Production. Ont. Farmer 2006, 9, 10-12.

15. Ryant, P.; Hřivna, L. The effect of sulphur fertilisation on yield and technological parameters of wheat grain. Ann. Univ. Mariae Curie-Skłodowska Sec. E 2004, 59, 1669-1678.

16. Sedlar, O.; Balik, J.; Kulhanek, M.; Cerny, J.; Suran, P. Sulphur nutrition in relation to nitrogen uptake and quality of winter wheat grain. Chil. J. Agric. Res. 2019, 79, 486-492. [CrossRef]

17. Hoque, M.A. Effect of Sulphur and Boron on Yield, oil Content and Nutrient Uptake of Mustard (Brassica juncea L.). Master's Thesis, Bangladesh Agricultural University (BAU), Mymensingh, Bangladesh, 2000.

18. Banerjee, A.; Chattopadhyay, G.; Boyd, C. Determination of critical limits of soil nutrients for use in optimizing fertilizer rates for fishponds in red, lateritic soil zones. Aquac. Eng. 2009, 40, 144-148. [CrossRef]

19. Tandon, H.L.S. Management of Nutrient Interaction in Agriculture; FDCO: New Delhi, India, 1992.

20. Singh, V.K.; Agarawal, H.P. Development of Dris norms for evaluating, nitrogen, phosphorus potassium and sulphur requirements of rice crop. J. Indian Soc. Soil Sci. 2007, 55, 294-303.

21. Murthy, I.Y.L.N. Critical nutrient limits in major oil seed crops-A review. Fertil. News 2004, 49, 51-55.

22. Bloem, E.; Haneklaus, S.; Schnug, E. Optimization of a method for soil sulphur extraction. Commun. Soil Sci. Plant. Anal. 2002, 33, 41-51. [CrossRef]

23. McLean, E.O. Soil pH and Lime Requirement. In Methods of Soil Analysis, Part 2, Chemical and Microbiological Properties; Page, A.L., Miller, R.H., Keeney, D.R., Eds.; American Society of Agronomy, Inc.: Madison, WI, USA, 1982; pp. $199-224$.

24. Bouyoucos, G.J. Hydrometer method improved for making particle size analysis of soils. Agron. J. 1962, 54, 464-465. [CrossRef]

25. Nelson, D.W.; Sommers, L.E. Total Carbon, Organic Carbon and Organic Matter. In Methods of Soil Analysis, Part 3, Chemical Methods; Sparks, D.L., Page, A.L., Helmke, P.A., Leoppert, R.H., Soltanpur, P.N., Tabatabai, M.A., Johnston, C.T., Sumner, M.E., Eds.; American Society of Agronomy, Inc.: Madison, WI, USA, 1996; pp. 961-1010.

26. Bremmer, J.M.; Mulvaney, C.S. Total nitrogen. In Methods of Soil Analysis, Part 2, Chemical and Microbiological Properties; Page, A.L., Miller, R.H., Keeney, D.R., Eds.; American Society of Agronomy, Inc.: Madison, WI, USA, 1982; pp. 595-624.

27. Olsen, S.R.; Sommers, L.E. Phosphorus. In Methods of Soil Analysis, Part 2, Chemical and Microbiological Properties; Page, A.L., Miller, R.H., Keeney, D.R., Eds.; American Society of Agronomy, Inc.: Madison, WI, USA, 1982; pp. 403-430.

28. Bray, R.H.; Kurtz, L.T. Determination of total organic and available forms of phosphorus in soils. Soil Sci. 1945, 59, 39-45. [CrossRef]

29. Peterson, L. Analytical Methods Soil, Water Plant Material Fertilizer; Soil Research Division Institute: Kumasi, Ghana, $2002 ;$ pp. 21-24.

30. Page, A.; Miller, R.H.; Keeney, D.R. Methods of Soil Analysis. Part 2, 2nd ed.; American Society of Agronomy, Inc.: Madison, WI, USA, 1982

31. Hunter, A.H. Soil Fertility Analysis Services in Bangladesh Constancy Report; BARC: Dhaka, Bangladesh, 1984.

32. Cate, R.B.; Nelson, L.A. Graphical procedure for critical limits of nutrients. Proc. Soil Sci. Soc. Am. 1965, 89, 658.

33. Waugh, D.L.; Cate, J.R.; Nelson, L.A. International soil fertility evaluation and improvement program. Tech. Bull. $1973,7,1-77$. 
34. Gomez, K.A.; Gomez, A.A. Statistical Procedure for Agricultural Research, 2nd ed.; John Willey \& Blackwell: Hoboken, NJ, USA, 1984.

35. BARC. Fertilizer Recommendation Guide; Bangladesh Agricultural Research Council: Dhaka, Bangladesh, 2018.

36. Chien, S.H.; Gearhart, M.M.; Villagarcía, S. Comparison of ammonium sulfate with other nitrogen and sulfur fertilizers in increasing crop production and minimizing environmental impact: A review. Soil Sci. 2011, 176, 327-335. [CrossRef]

37. Pareek, F.; Ghazanchi, R. Study of the effect of chemical fertilizers, compost and their combination on Aloe vera growth and yield. Sci. Res. 2012, 5, 64-66.

38. Huda, M.N.; Islam, M.R.; Jahiruddin, M. Evaluation of Extractants and Critical Limits of Sulphur in Rice Soils of Bangladesh. Asian J. Plant. Sci. 2004, 3, 480-483. [CrossRef]

39. Fox, R.L.; Olsen, R.A.; Rhoades, H.F. Evaluating the sulphur status of soils by plant and soil tests. Soil Sci. Soc. Am. Proc. 1964, 28, 243-246. [CrossRef] 